\title{
SUSTAINABLE TOURISM DEVELOPMENT OF COASTAL DESTINATION - THE ROLE AND THE SIGNIFICANCE OF LOCAL RESIDENTS
}

\author{
Draženka Birkić \\ Andreja Primužak \\ Nela Erdeljac
}

https://doi.org/10.20867/tosee.05.21

\begin{abstract}
Purpose - The main paradigm of sustainable tourism development are local residents, that is, their direct and indirect support in the process of sustainable touristic planning and development of any touristic destination in the world. Their attitude needs to be taken into account during the decisionmaking processes regarding future tourism development and local residents need to find their own interest (employment, ensuring a better standard of living, the possibility of entrepreneurial activities, market for new products, improvement of infrastructure and so on.). Local selfgovernment is responsible for monitoring and recognizing the need and expectations of local residents. The aim of this paper is the examination of local residents' attitudes with regard to the development of tourism and the establishment of tourism development in observed Adriatic coastal destinations.

Methodology - Research was conducted in 2016 in 9 Adriatic coastal destinations via survey questionnaire, created according to the SUS-TAS model Choi and Shirakaya (2005), using the social dimension of the model. The research consisted of 371 subjects, all local residents, older than 18. The data gathered was analyzed using appropriate statistical methods with the help of a software program for social sciences Statistica, Ver. 12. Correlations analysis and factor analysis were used from the statistical methods in order to determine the attitude of local residents in researched tourism destinations.

Findings - The results of this research show that local residents do not support the current direction of tourism development in researched coastal destinations and are aware of all the negative consequences of the development of mass tourism that is not governed by the principles of sustainable tourism development. Three main components of sustainable tourism, long-term planning, full community participation and sustainability of the environment in tourism, are areas in which local residents wish to be actively represented in the decision-making process.

Contribution - Research data presented by this paper can suggest critical implications to local authorities who should take them into account when considering tourism development, including the role and significance of local residents without whose active participation there is no sustainable tourism development. The initiative for tourism development based on the principles of sustainable development needs to come from the local community, from the local residents, who need to understand that, in tourism, economic benefits are brought on by ecological responsibility, that is, not exhausting the local environment as the primary tourism resource and conservation of natural and built attractions. Therefore, the necessary task of those conducive to development, primarily local authorities, developmental agencies, destination management organizations, is the improvement of channels of communication and coordination.
\end{abstract}

Keywords Coastal tourist destination, sustainable tourism development, local residents, impact of local residents, local self-government 
ToSEE - Tourism in Southern and Eastern Europe, Vol. 5, pp. 101-119, 2019

D. Birkić, A. Primužak, N. Erdeljac: SUSTAINABLE TOURISM DEVELOPMENT OF COASTAL ...

\section{LITERATURE REVIEW}

The term local population describes all people that live within a coastal destination. There exist the so-called "external population" that included people that do not live in a given coastal destination, but have the legitimite right to be included in certain decisions. They were born in the destination, moved, but still have certain connections with the area. Local population is not a homogenous group. Researching the characteristics and participation of local population in tourism development Tosun (2000, in Saufi et al., 801:2014), identified three groups of local population. The first ones are spontaneous participants, which includes voluntarily engaged local population whose ideas and thoughts about tourism development comes from the community, which realizes them. The other group presents induced participants who were called to submit ideas about tourism development to their local authorities, which, in the end, is responsible for the decision-making processes regarding tourism development. The third group are the socalled corrective group, which emerges and works when tourism development is done under the guise of the need of local population and destination, but in reality, such tourism development represents interests of outside participants such as foreign corporations, legislative power or tour operators. As its name suggests, the aim of their participation is to correct the decisions about tourism development that are not in the interest of the community. Local population, with its natural and cultural heritage, traditional values assignes specific characteristic through which a destination becomes attractive for visitors. It has an important role in the development of tourism and its active participation is considered to be the key to the development of sustainable tourism community (Cole, 2006; Tosun, 2006; Saufi, O'Brien, Wilkins, 2014). It is directly interested in its successful growth and development and the participation of local community is necessary to look at from two perspectives. The first one is to recognize expectations of the local community within tourism planning and the concerns of the development of tourism, the other on whether or not the local community benefits from tourism growth and development of their community and how that benefit is distributed within the society. The participation of local community in strategic planning included the right to revise the process of tourism development. Numerous studies which researched the participation of local population in tourism development suggest that their correlation for inclusion in tourism and their behavior towards tourists in their area are strong indicators of the sustainability of tourism (Jurowsky i Gursoy, 2004; Weawer i Lawton, 2006, Choi i Shirakaya 2010; Vargas-Sáchez et al., 2011, Saufi et al., 2014).

The level of local community participation in tourism development is closely associated with a sustained level of knowledge and ability to control and manage local tourism resources so that Cole (2006) considers adequate knowledge about tourism empowers the host community and engages it in tourism development. Therefore, local community participation requires the development of politics in the line of educating the local population on the local, regional and national level.

According to Cole (2006), in many developing countries, the participation of the community, that is local population in tourism growth and development, is restricted on the way they could participate. Institutional factors such as centralized decision-making process, unwillingness of tourism planners to include local population, creating tourism plans and the lack of knowledge about tourism significantly impacts the restricted 
ToSEE - Tourism in Southern and Eastern Europe, Vol. 5, pp. 101-119, 2019

D. Birkić, A. Primužak, N. Erdeljac: SUSTAINABLE TOURISM DEVELOPMENT OF COASTAL

participation of local self-government in tourism growth and development. Secondly, the structural restrictions that are connected to institutional factors such as regional structures of power, legislature power and economic systems. Shortcomings on this level may lead to centralized and too much of a birocratic way of decision-making. Third, cultural restrictions are connected to low levels of local population competence in the development of resource related problems of tourism (Louw, Smart, 1998; Teye et al., 2002; Timothy, 1999, Sufi et al., 803:2014).

Under the term of local population participation, we may say it includes all tourist undertakings through which a local community works, with the retention of economic benefits on the local level and the positive social outcomes such as education and qualitifactions connected to tourism (Saufi et al., 803, 2014). From the perspective of tourism development, this concept of community participation is in accordance with Sceyvenson (2002) who claims that local community undertakings are supposed to be successful only if local community participation brings certain measures of control on the usage of tourism resources and if they have equal share in the distribution of economic and social benefits which derive from tourism. The obstacles participation for the participating host are specific for each tourism destination, depending on their social and cultural context of local community and the extent of development within an area (Saufi et al., 803, 2014). Local public self-government should identify those obstacles and work on their removal.

The attitude of the local community towards tourism is under the influence of various factors, Lankford and Howard (1994) defined the scale of ten variables that impact the local population attitude about tourism, and those are: the length of living within the community, economic dependence on tourism, the distance from the place of tourism activities, the inclusion of the decision-making about tourism, the place of birth, the level of knowledge, the level of contact with tourism, demographic characteristics, the understandings of the impact on the possibility of outside recreational activities and the level of wealth growth.

Furthermore, Getz (1994) claims the attitude of the local community is under strong influence of their experience and they have strong associations with their values and idiosyncrasies. According to Choi and Murray, numerous studies conclude that the local residents economically benefit the most and the sociocultural improvements that accompany the development of tourism are enormous(Choi i Murray, 2010:576). On the hand, Murphy (1981) considers the local community's opinion about tourism from two different perspectives: the visually esthetic and in the way it physically shapes the community. In other words, people who see damage done by tourists to the community in the sphere of increasing garbage, noise, vandalism, traffic jams, are less enthusiastic about tourism. Equally, pollution, individual and collective crime, thievery, overcrowding, prostitution, trash, alcoholism, disturbance of the everyday life of the population, problems connected with the lack of parking space lessen the quality of life of local population in the tourism destination (Choi i Muray, 2010: 578). When planning the touristic development of a destination, local self-government and destination's management should take into account the wishes, the suggestions and the initiatives of the local population because only then will a systematic and quality tourism development be possible, and also the shortcomings and the negative attitudes of the local population 
ToSEE - Tourism in Southern and Eastern Europe, Vol. 5, pp. 101-119, 2019

D. Birkić, A. Primužak, N. Erdeljac: SUSTAINABLE TOURISM DEVELOPMENT OF COASTAL

towards tourism will be lessened. Certain research in the area of tourism shows that local population is marginalized and subordinate to the process of tourism development and that local population should be increasingly more included in the process of tourism planning and growth process (Choi and Shirakay, 2005: 381). The involvement of the local population in the decision-making process regarding the development of tourism is a key indicator of sustainable tourism development of the community. Namely, direct and indirect support of the participation of the local population in the community provides the basics of the paradigm of sustainability (Choi and Shirakay, 2005.). Including the local community in the process of destination management is not an easy process.

According to Jenkins (1993, 281-290), the reasons are the following:

- the local population has problems with understanding complex technical-planning questions of the development of sustainable tourism

- the local population in general does not understand how the plan process works and how decisions are made

- $\quad$ the problem of consideration and appreciation of all the possibilities of commenting in the process of decision making

- most of the citizens show apathy, i.e. indifference for participation in the decisionmaking process about the future tourism development of a coastal destination

- the process of inclusion of local population in the process of planning and governing of the coastal area increase the cost

- the process of decision making lasts a lot longer if the local population is included

- the overall efficiency of the process is reduced because the overall process of planning and decision making lasts a lot longer

The majority of stated reasons brings to the conclusion that the biggest problem is unwillingness, that is a low level of knowledge and capability of the local community, local population, to take over a part of the responsibility of the development into their own hands. Along with that, there is a problem with communication and coordination of set objectives necessary for the inclusion of the local population. Therefore, the key task of responsible project developers, namely the local authorities, development agencies and the destination management organization, is to have a positive impact on the local community, to encourage it to participate in the creation of development plans.

In practice, it is possible to come across examples where efforts have been made to include the local population in the process of planning the development of the tourism of a destination ( Birkić et al., 2014, Inskeep, 1991; Dredge i Moore, 1992; Dowling, 1993; Long i Nuckolls, 1994). But these efforts are, however, usually insignificant. The main role of the community is limited to the possibilities of commenting the appropriateness of the solutions offered by the institutional planners, and it is possible to conclude that the consultation of the community definitely exists, but that the participation is not as likely.

It has been noted that the term participation often includes terms that don't really mean participation of the local population in the decision- making process and that the local population has been marginalized and subordinate to the process of tourism development. Local self-government is the most appropriate for the coordination, that is, 
ToSEE - Tourism in Southern and Eastern Europe, Vol. 5, pp. 101-119, 2019

D. Birkić, A. Primužak, N. Erdeljac: SUSTAINABLE TOURISM DEVELOPMENT OF COASTAL ...

inclusion of the local population in the process of long-term planning, with the aim of establishing sustainable tourism development on the local level and for encouraging programs of sustainable tourism development (Bramwell, 2011). It includes the institutional system that has political power and might for effective systematic management of sustainable tourism development. The implementation of sustainable tourism development of coastal destination, noting the attitude and opinions of local population is closely related to the capability and the authority of the local government, responsible for a certain tourism destination.

Financial power, economic priorities, social needs and political influences often characterize the interactions of certain developmental participants both at the planning stage of developmental and spacial tourism developmental plans as well as the implementation phase (Altinay and Bowen, 2006). During that time ruling political and/or economic elites, in most cases, use the aggressive approach try to impose their short-term partial interests in determining the needs of appropriate spacial resources (Shamsul and Haque, 2007; Choi and Sirakaya, 2006), without taking into account longterm interests of the local community in the whole

\section{METHODOLOGY AND DEFINING THE RESEARCH SAMPLE}

Tourism experts have been developing models for research and assessment of local resident attitudes towards tourism. This paper used the research model SUS-TAS which was developed by Choi and Shirakaya (2005). Research subject is the attitude of local residents with regard to tourism development and the setting up of sustainable tourism development. SUS-TAS model as such is strongly focused on actual questions regarding the impact of tourism and attitude of local residents with regard to tourism development and the establishment of sustainable tourism planning.

SUS-TAS model is developed using exploratory factor analysis EFA (Exploratory faktor analysis). This analysis aims to describe and summarize data in a way that they group together variables that are in correlation. Exploratory factor analysis is conducted in early research phrases, when consolidating variables and hypotesis setting for main processes is set. Using the Varimax rotation, authors have determined 44 variables for seven construction domains. These are: ecological construct, social cost construct, long-term planning construct, economic benefits construct, tourism based on the community, insurance of the satisfactory of customers, participation of local residents in the community. For the purpose of this model, the authors developed standard psychometric procedure of developing a scale that has seven phases (Churchill 1979, DeVilis, 1991): 1. Determine what needs to be counted, 2. Generate items in order to scale the construction of interest, 3. Develop the final items list, 4. Determine the kind of scale of evaluation, 5. Determine the cleanliness of the scale (checking the credibility and legitimacy), 6. Cleaning the study with the aim of qualifying (reevaluation of the credibility and validity of the scale using the analysis of affirmative factors), 7 . Norm development (the development of standards and norms for decision makers). 
ToSEE - Tourism in Southern and Eastern Europe, Vol. 5, pp. 101-119, 2019

D. Birkić, A. Primužak, N. Erdeljac: SUSTAINABLE TOURISM DEVELOPMENT OF COASTAL ...

Relative literature on tourism and world examples from practice (Bramwell, 2011) show that the attitude of local residents has significant impact on tourism development. Thus, understanding the attitude of residents can help the creators of politics and development planners to estimate the perception of the community better with regard to the course of tourism development. The aim of such a developed model is to contribute to the knowledge of local residents' attitude towards tourism development and the establishment of sustainable tourism development. Understanding and monitoring the benefits of residents on local and regional levels is key for developing public policies whose aim is to better the society (OECD, 2016). This research SUS-TAS model was adapted in accordance to cultural, linguistic and research aims. The attitude of local residents in managing sustainable tourism of a destination has been researched (in the following order): F1 The impact of tourism on the environment of the community; F2 The impact of tourism on the quality of life of the local population; F3 the impact of tourism on local economy; F4 The impact on the attitudes amoung the local community when it comes to engaging the local community in the development of tourism; F5 Strategic thinking about the development of tourism by the local community; F6 The impact of tourism on local employment. We conducted a survey questionnaire in 9 Adriatic tourism destinations: Poreč, Rovinj, Medulin, Opatija, Crikvenica, Novi Vinodolski, Zadar, Sv. Filip i Jakov and Biograd na Moru and choose local residents from those Adriatic destinations older than 18. Fieldwork consisted of 510 questionnaires sent, out of which 371 were sent back so the return was $73 \% .63,07 \%$ of women and $36,93 \%$ of man participated in the research with the most prominent age group being between 31 and 40 and presented the $24,80 \%$ of participants. Relating to the educational structure, the most prominent group were those with high school diplomas, 57,14\%. Graf icon 1. further shows the structure of participants according to the demographic characteristics in the researched coastal tourist destinations.

\section{Graph 1: Structure of examinees according to demographic characteristics}

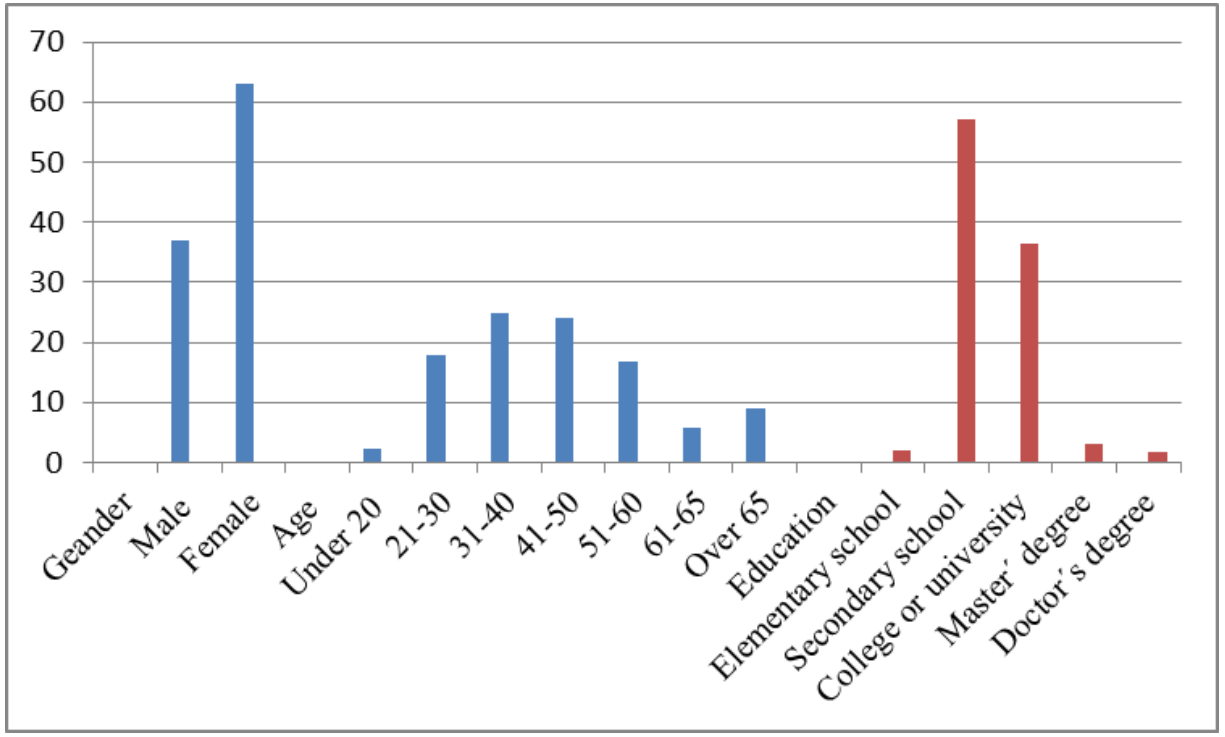

Source: Authors' analysis, June, 2016 
ToSEE - Tourism in Southern and Eastern Europe, Vol. 5, pp. 101-119, 2019

D. Birkić, A. Primužak, N. Erdeljac: SUSTAINABLE TOURISM DEVELOPMENT OF COASTAL ...

The biggest response was in Sv. Filip and Jakov, where the return of survey questionnaire was $85 \%$ while Opatija had the lowest $(44 \%)$.

\section{Graph 2: The structure of the subjects who responded to the research according to the place of residence}

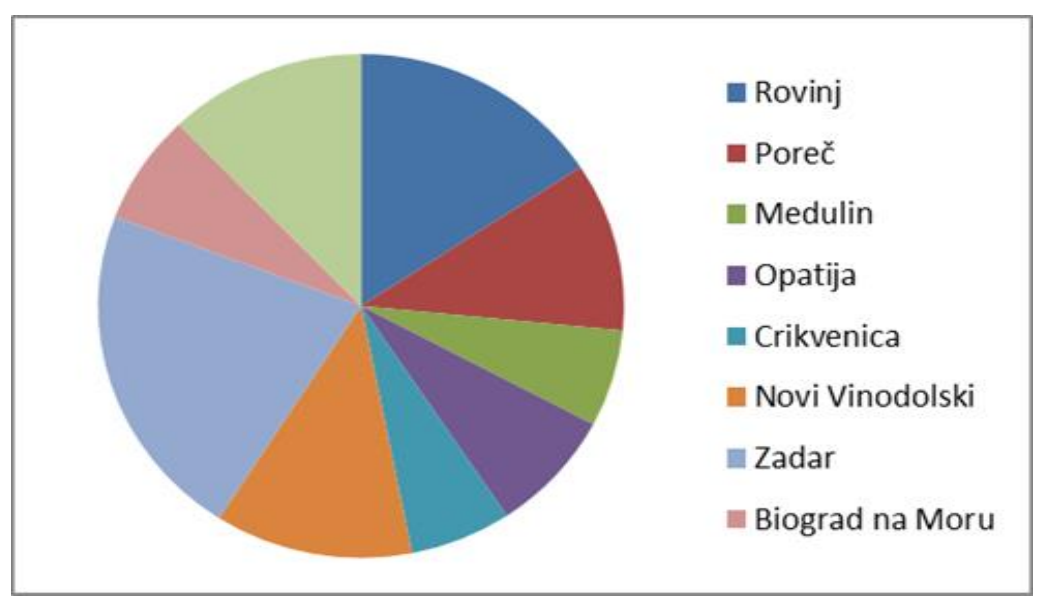

Source: Authors' analysis, June 2016

According to Lankford and Howard (1994) a variable, economic development of tourism, the places that depend on tourism, e.g. if they are directly or indirectly employed in tourism prefer tourism. In this research almost 60,92 percent of subjects who participated are not employed in tourism, but $23,72 \%$ of them are engaged in apartment renting to tourists, $39,08 \%$ of them work in tourism, with $21.29 \%$ subjects employed in tourism during tourism season, which is visible in table 1 .

\section{Table 1: Structure of respondents, by employment in tourism}

\begin{tabular}{|l|c|c|c|}
\hline $\begin{array}{l}\text { Employment of the subject or member of his } \\
\text { family in tourism }\end{array}$ & $\begin{array}{c}\text { Number of } \\
\text { subjects }\end{array}$ & $\begin{array}{c}\text { Structure } \\
\text { in } \%\end{array}$ & $\begin{array}{c}\text { Cumulative } \\
\%\end{array}$ \\
\hline Yes, full time employment & 66 & 17,79 & 17,79 \\
\hline Yes, only seasonable employment & 79 & 21,29 & 39,08 \\
\hline No & 138 & 37,20 & 76,28 \\
\hline No, but is involved in apartment renting & 88 & 23,72 & 100,00 \\
\hline Total & 371 & 100,00 & \\
\hline
\end{tabular}

Source: research by the author, June 2016

Scientific research, formulating and presenting the results of this research was conducted by applying general methodological principles, standard for economic research.

Dana collected by primary research were analyzed using the appropriate statistical methods with the help of the software program for social sciences Statistica, Ver. 12. Based on such collected and processed data, the research results were formulated and grouped in tables and graphs and visual demonstrations as follows: 
ToSEE - Tourism in Southern and Eastern Europe, Vol. 5, pp. 101-119, 2019

D. Birkić, A. Primužak, N. Erdeljac: SUSTAINABLE TOURISM DEVELOPMENT OF COASTAL ...

\section{RESEARCH RESULTS}

The reliabity of research was tested by calculation Cronbach alpha index. Therefore, for each of the group variables Cronbach's aplha index was calculated and that way testing the reliability and credibility of applied scales of measurement. Cronbach Alpha coefficient, one of the most used coefficients for determining the reliability of scales of measurements, presents the measurement of internal consistency and can take value between 0 and 1. According to Cronbach Alpha, the more the coefficient is closer to the value of 1 the scales of measurement are more reliable. The regular criteria for Cronbach alpha coefficients (DeVellis, 1991) are listed in Table 2.

\section{Table 2: Acceptable and unacceptable levels of Cronbach's alpha reliability} coefficient

\begin{tabular}{|l|l|}
\hline Alfa coefficient & implied reliability \\
\hline below 0.60 & unacceptable \\
\hline $0.60-0.65$ & borderline \\
\hline $0.65-0.70$ & acceptable \\
\hline $0.70-0.80$ & very good \\
\hline $0.80-0.90$ & excellent \\
\hline behind 0.90 & scale needs to be shortened \\
\hline
\end{tabular}

Source: DeVellis, 1991.

Table 3 shows the variable sum of the indicator of tourism development based on the principles of sustainable tourism. In order to determine is it justified to use variable of F1 to F6 as group indicators of tourism development based on the principles of sustainable development, Cronbach's alpha determiner was calcuated for each of the group variables.

Table 3: The sum variables of tourism indicator based on the principles of sustainable development

\begin{tabular}{|l|c|c|c|c|c|c|}
\hline Name of the variable & $\mathrm{N}$ & Min. & Max. & Standard & St.Dev. & $\begin{array}{c}\text { Cronbach's } \\
\text { alpha }\end{array}$ \\
\hline $\begin{array}{l}\text { F1. Impact of tourism on } \\
\text { the environment of the } \\
\text { community }\end{array}$ & 371 & 1,222 & 5 & 3,604 & 0,664 & 0,829 \\
\hline $\begin{array}{l}\text { F2. Impact of tourism on } \\
\text { the quality of life }\end{array}$ & 371 & 2,000 & 5 & 3,814 & 0,678 & 0,854 \\
\hline $\begin{array}{l}\text { F3. Impact of tourism on } \\
\text { economy }\end{array}$ & 371 & 1,167 & 5 & 4,231 & 0,704 & 0,901 \\
\hline $\begin{array}{l}\text { F4. Attitude of the need } \\
\text { for including local } \\
\text { community in tourism } \\
\text { development }\end{array}$ & 371 & 2,000 & 5 & 4,384 & 0,687 & 0,897 \\
\hline $\begin{array}{l}\text { F5. Strategic } \\
\text { comprehension of } \\
\text { tourism development by } \\
\text { the local community }\end{array}$ & 371 & 2,250 & 5 & 4,518 & 0,544 & 0,898 \\
\hline
\end{tabular}


ToSEE - Tourism in Southern and Eastern Europe, Vol. 5, pp. 101-119, 2019

D. Birkić, A. Primužak, N. Erdeljac: SUSTAINABLE TOURISM DEVELOPMENT OF COASTAL ...

\begin{tabular}{|l|c|c|c|c|c|c|}
\hline Name of the variable & $\mathrm{N}$ & Min. & Max. & Standard & St.Dev. & $\begin{array}{c}\text { Cronbach's } \\
\text { alpha }\end{array}$ \\
\hline $\begin{array}{l}\text { F6. The impact of tourism } \\
\text { on local employment and } \\
\text { local budget }\end{array}$ & 371 & 2,167 & 5 & 3,909 & 0,600 & 0,729 \\
\hline
\end{tabular}

Source: Survey by local residents, June 2016.

The results of the analysis of the reliability of the measuring scale, as is shown in table 3 , show that the scale of measurement used for the construction of variables of indicators for tourism development based on the principles of sustainable development from F1 to F6 posess satisfactory level of reliability, which is determined through the value of Cronbach's alpha indicator higher that 0,7 for each of the group variables.

In the following pages, the results of our research, which will explain in more detail the attitude of local residents with regard to the current tourism development of the places in which residents' life, will be presented.

Table 4 gives a review of the estimate of the status according to subjects, local residents on the impact of tourism on the environment of the community in the researched coastal destinations. Subjects were asked to scale, from 1-5, their estimations of the impact tourism has on the environment of the community in which they live (1-I do not agree at all; 5- I strongly agree).

Table 4: Estimation of the subjects' attitude on the impact of tourism for the community environment

\begin{tabular}{|l|l|c|c|c|c|c|}
\hline Code & $\begin{array}{l}\text { F1. Impact of tourism on the } \\
\text { environment of the community }\end{array}$ & $\mathrm{N}$ & Min. & Max. & Standard & St.Dev. \\
\hline F1_1. & $\begin{array}{l}\text { The environment of the community } \\
\text { in my area is protected now and for } \\
\text { the future }\end{array}$ & 371 & 1 & 5 & 3,09 & 1,10 \\
\hline F1_2. & $\begin{array}{l}\text { The natural diversity in my area is } \\
\text { cherished and protected }\end{array}$ & 371 & 1 & 5 & 3,26 & 1,05 \\
\hline F1_3. & $\begin{array}{l}\text { The tourism industry of my area } \\
\text { needs to enhance the efforts for the } \\
\text { preservation of the environment }\end{array}$ & 371 & 1 & 5 & 4,07 & 0,90 \\
\hline F1_4. & $\begin{array}{l}\text { Tourism industry in my area protects } \\
\text { the environment of the community }\end{array}$ & 371 & 1 & 5 & 3,26 & 1,04 \\
\hline F1_5. & $\begin{array}{l}\text { Tourism in my area is developed in } \\
\text { accordance with the natural and } \\
\text { cultural surroundings }\end{array}$ & 371 & 1 & 5 & 3,28 & 1,13 \\
\hline F1_7. & $\begin{array}{l}\text { Tourism development of my area } \\
\text { encourages positive ethics on } \\
\text { environment protection among all } \\
\text { interested parties in my area }\end{array}$ & 371 & 1 & 5 & 3,30 & 1,12 \\
\hline F1_8. & $\begin{array}{l}\text { Regulations regarding the standards } \\
\text { of the environment are necessary in } \\
\text { order to lessen the negative effects of } \\
\text { tourism development }\end{array}$ & 371 & 1 & 5 & 4,08 & 0,85 \\
\hline
\end{tabular}


ToSEE - Tourism in Southern and Eastern Europe, Vol. 5, pp. 101-119, 2019

D. Birkić, A. Primužak, N. Erdeljac: SUSTAINABLE TOURISM DEVELOPMENT OF COASTAL ...

\begin{tabular}{|l|l|c|c|c|c|c|}
\hline Code & $\begin{array}{l}\text { F1. Impact of tourism on the } \\
\text { environment of the community }\end{array}$ & $\mathrm{N}$ & Min. & Max. & Standard & St.Dev. \\
\hline F1_9. & $\begin{array}{l}\text { I believe that the tourist industry can } \\
\text { become better and protect the } \\
\text { environment of my area for future } \\
\text { generations. }\end{array}$ & 371 & 1 & 9 & 3,94 & 1,01 \\
\hline F1_10. & $\begin{array}{l}\text { Ecological preservation of my area is } \\
\text { the most important element of } \\
\text { tourism desirability of the } \\
\text { community for visitors }\end{array}$ & 371 & 1 & 5 & 4,15 & 0,97 \\
\hline
\end{tabular}

Note: (1- I do not agree at all, 5- I strongly agree)

Source: Local resident questionnaire, June,2016.

According to the results presented, table 4, it is possible to notice a high level of correspondence of local residents with claims that relate to possibilities of improvement of the state of the environment of the community. Based on the given assessment to claims F1-10. The environment of the community in my area is protected for now and the future 3.09, F1_2 The natural diversity in my area is cherished and protected 3.26, F1_4 Tourism industry in my area protects the environment of the community 3.26., Tourism in my area is developed in accordance with the natural and cultural surroundings 3.28 and which relate to protection and preservation of researched tourism destinations. From the aspect of local residents, we can conclude that not a single local selfgovernment or tourist industry does not give full attention and significance to these segments and that is reflected on the attitude of local residents which is, according to shown grades in table 4 , unsatisfactory.

Local residents consider that in their destinations natural diversity is not valued and protected, not for current nor for future generations, and if it is, it is done in limited scope and the environment is not protected enough nor now nor for future generations. Therefore, from the set out grades of subjects, we can conclude that local residents are not full satisfied with the state of the environment in the community and consider that competent institutions and tourist industries do not invest a lot of effort in the preservation of natural resources and original environment.

The information that until 2000, $15 \%$ of Croatian Adriatic coast was urbanized and built is also indicative and urbanistic plans which are in force now have enabled further urbanization for $27 \%$ of the coastal line (Hrabak, 2014). According to data from DCZ (2015) in researched coastal tourism destinations in 2011, 106829 housing units have been documented, aprox. 32\% more than 2001. From that, in 2011, 27145 housing units for rest and recreation, for renting to tourists respectively, have been documented and that represents a share of $25 \%$, respectively, the increase of the number of apartments for resting and recreation in 2011, compared to 2001, for even 60,4\%. Among others, the so-called "apartmenization" apropos sealing is surely in one way a hazard to permanent land degradation. In the light of all foregoing, we can conclude that tourism in researched coastal destinations is not being developed in accordance with the natural and sociocultural surroundings. Data showed in this paper might point to irresponsible behavior of local residents, which can be seen in excessive and uncontrollable building of tourism accommodation capacities in terms of cottages, houses and holiday houses. 
ToSEE - Tourism in Southern and Eastern Europe, Vol. 5, pp. 101-119, 2019

D. Birkić, A. Primužak, N. Erdeljac: SUSTAINABLE TOURISM DEVELOPMENT OF COASTAL ...

The quality of life in researched coastal destinations was researched through estimation of capabilities of local community to accept new inputs, in this case tourists for shorter or longer periods that, despite that, keep functioning without social disharmony which those inputs can bring. Their attitudes subjects were graded with grades 1 to 5 (1-I do not agree at all; 5- I strongly agree).

Table 5: Subject estimates on the impact of tourism on the quality of life

\begin{tabular}{|c|l|c|c|c|c|c|}
\hline Code & $\begin{array}{l}\text { F2. The impact of tourism on the quality } \\
\text { of life }\end{array}$ & $\mathrm{N}$ & $\mathrm{Min}$ & $\mathrm{Max}$ & Standard & St.Dev. \\
\hline F2_1. & $\begin{array}{l}\text { Tourists and their visits do not disrupt } \\
\text { the quality of my life in my area }\end{array}$ & 371 & 1 & 5 & 3,73 & 1,15 \\
\hline F2_2. & $\begin{array}{l}\text { The quality of life in my area has not } \\
\text { deteriorated because of tourism }\end{array}$ & 371 & 1 & 5 & 3,94 & 1,03 \\
\hline F2_3. & $\begin{array}{l}\text { I am rarely upset because of tourism } \\
\text { movement in my area }\end{array}$ & 371 & 1 & 5 & 3,85 & 1,01 \\
\hline F2_4. & $\begin{array}{l}\text { Recreational resources of the community } \\
\text { are not used excessively by tourists }\end{array}$ & 371 & 1 & 5 & 3,59 & 0,94 \\
\hline F2_5. & $\begin{array}{l}\text { My tourism area is not } \\
\text { crowded/smothered because of tourism } \\
\text { development }\end{array}$ & 371 & 1 & 5 & 3,55 & 1,10 \\
\hline F2_6. & $\begin{array}{l}\text { I feel content/welcomed in local tourist } \\
\text { attractions }\end{array}$ & 371 & 1 & 5 & 3,68 & 1,00 \\
\hline F2_7. & $\begin{array}{l}\text { Tourism in my area is not growing too } \\
\text { fast }\end{array}$ & 371 & 1 & 5 & 3,77 & 0,98 \\
\hline F2_8 & $\begin{array}{l}\text { I believe that the quality of the } \\
\text { environment in my area has not } \\
\text { deteriorated because of tourism }\end{array}$ & 371 & 1 & 5 & 3,77 & 1,00 \\
\hline
\end{tabular}

Note: (1- I don't agree at all, 5- I strongly agree)

Source: Local residents questionnaire, June 2015

With regard to the results of research, as shown in table 5, we can conclude that the quality of life of local residents is somewhat endangered and that local populations feels it in their daily life. In support of that claim, low grades submitted to further claims F25. My tourism area is not crowded/smothered because of tourism development 3,55; F2_4 Recreational resources of the community are not used excessively by tourists 3,59; F2_6 I feel content/welcomed in local tourism contents 3,68. But with regard to the benefits that tourism brings with itself a level of tolerance with local residents with the question of violation of the quality of life in the community does exist. We can find the reason for it in the fact that the basic characteristic of tourism in coastal tourist destination, seasonality and mass, means this state lasts for only short periods of time during the year, only 3-4 months.

When we talk about economic interests of local residents, then we first consider the employment of residential (local) residents, respectively income generating within the framework of a variety of activities that make the system of tourism, which are the source of material base in this area. Tourist industry today in the world, directly or indirectly, employs around 200 million people who, under certain estimates, participate with 6 to $7 \%$ in full employment (Conrady and Buck, 2011). According to estimates, that number will rise to 280 million by 2018 (Slack, Chambers and Johnston, 2010; Williams, 2009; 
ToSEE - Tourism in Southern and Eastern Europe, Vol. 5, pp. 101-119, 2019

D. Birkić, A. Primužak, N. Erdeljac: SUSTAINABLE TOURISM DEVELOPMENT OF COASTAL ...

Timotthy and Tey, 2009). Thereby, the biggest number of employed in activities connected to tourism is in hotel management, hospitality and mediation activities in traveling. The understanding of perception of local residents on the impact of tourism on economic and social growth and development of the community, is important for their further direction of the development of tourism industry. Perception of local residents and their attitudes on the impacts of tourism development should constantly be reevaluated in order for the tourism industry to be directed towards socially accepted area of development. In this accordance, along the line of this paper, table 6 shows the results of research that deals with the estimation of the impact of tourism on economic growth and development of local community by local residents. The subjects were asked, using the grades 1 to 5 , to evaluate the impact of tourism on economic growth and development of local community (1-I do not agree at all; 5- I strongly agree).

Table 6: Descriptive statistics of the evaluation of the subjects on the impact of tourism on the economy

\begin{tabular}{|c|l|c|c|c|c|c|}
\hline Code & $\begin{array}{l}\text { F3. The impact of tourism on the } \\
\text { economy }\end{array}$ & $\mathrm{N}$ & Min & Max & Standard & St.Dev. \\
\hline F3_1. & $\begin{array}{l}\text { I believe that tourism is the source of } \\
\text { high income in my area }\end{array}$ & 371 & 1 & 5 & 4,18 & 0,92 \\
\hline F3_2. & $\begin{array}{l}\text { Tourism creates important tax incomes } \\
\text { to the local self-government }\end{array}$ & 371 & 1 & 5 & 4,24 & 0,83 \\
\hline F3_3. & $\begin{array}{l}\text { I believe that tourism is good for the } \\
\text { economic development of my area }\end{array}$ & 371 & 1 & 5 & 4,40 & 0,70 \\
\hline F3_4. & $\begin{array}{l}\text { I believe that tourism creates new } \\
\text { markets for our local products }\end{array}$ & 371 & 1 & 5 & 4,27 & 0,88 \\
\hline F3_5. & $\begin{array}{l}\text { Tourism encourages the diverse } \\
\text { development of the local economy }\end{array}$ & 371 & 1 & 5 & 4,25 & 0,82 \\
\hline F3_6. & $\begin{array}{l}\text { Tourism encourages the growth and } \\
\text { development of other industries in the } \\
\text { community }\end{array}$ & 371 & 1 & 5 & 4,05 & 0,98 \\
\hline
\end{tabular}

Note: (1-I do not agree at all; 5- I strongly agree)

Source: Local residents questionnaire, June 2016.

Subjects graded the impact of tourism on the economic growth and development of researched coastal destinations with estimations that had a mean average value of 4.23. The analysis has shown that the majority of subjects agree with the claim I believe that tourism is good for economic development of my area. Residents mostly believe that tourism is good for economic growth and development of the coastal destinations and that claim recieved the highest average grade of 4,40. Regarding the development of tourism on economic growth and development of coastal destinations, here positive perceptions of local residents are clearly visible. In accordance with that, they are aware that tourism means creating new markets for local products (average grade 4,27), as well as that tourism encourages diverse economic development (average grade 4,25 ) and that tourism creates valuable tax benefits to local authority (average grade 4,24). The lowest grade was given to the claim Tourism encourages the growth and development of other industry in the community $(4,05)$ which can be a source of concern because instead of promoting "invisible export" tourism promotes "invisible import". The impact of tourism on local economy differs from destination to destination and deals with the sum of initial tourism expenditure created in economic activities that directly absorb tourism 
ToSEE - Tourism in Southern and Eastern Europe, Vol. 5, pp. 101-119, 2019

D. Birkić, A. Primužak, N. Erdeljac: SUSTAINABLE TOURISM DEVELOPMENT OF COASTAL ...

expenditure. The benefits that come out of the development of tourism necessarily need to be directed mainly towards satisfying the interests of local residents and afterwards on the satisfaction of the interests of other members within the coastal destination. One of the main challenges of 21 st century tourism is the question of sustainability of workplace in tourism. National authorities are facing great expectations to ease high levels of unemployment in underdeveloped and countries in development. The problem gets even more complicated when dealing with smaller coastal tourist destinations that do not have developed economy. The majority of workplaces in tourism do not generate an average high income but presents one of the more qualitative ways of employment, if not the only one. Since tourism is workwise an intensive activity, national, regional and local authorities often support tourism development and employment in tourism. The seasonal character of tourism demands significantly impacts the level of employment and workplace stability but that, at the same time, presents an obstacle to the efforts of increasing employment in tourism. Tourism demand thus creates more seasonal than full employment. This shape of employment has far fetched consequences, especially in economically underdeveloped areas and developing countries that are too dependent on tourism. The following table 7, gives an overview of the state by subjects, local residents, on the impact of tourism on local employment and local budget in researched coastal destinations (1- I don't agree at all; 5- I fully agree).

Table 7: Subject estimations on the impact of tourism on local employment and local budget

\begin{tabular}{|c|l|c|c|c|c|c|}
\hline Code & $\begin{array}{l}\text { F6. The impact of tourism on local } \\
\text { employment and local budget }\end{array}$ & $\mathrm{N}$ & Min & Max & Average & St.Dev. \\
\hline F6_1. & $\begin{array}{l}\text { Tourism industry needs to use at least } \\
\text { one half of assets and services from the } \\
\text { local community }\end{array}$ & 371 & 1 & 5 & 4,22 & 0,82 \\
\hline F6_2. & $\begin{array}{l}\text { Tourism industry uses one half of assets } \\
\text { and services from the local community }\end{array}$ & 371 & 1 & 5 & 3,41 & 1,01 \\
\hline F6_3. & $\begin{array}{l}\text { Tourism industry needs to hire at least } \\
\text { half of its employees from the local } \\
\text { community }\end{array}$ & 371 & 1 & 5 & 4,32 & 0,84 \\
\hline F6_4. & $\begin{array}{l}\text { Tourism industry hires half of its } \\
\text { employees from the local community }\end{array}$ & 371 & 1 & 5 & 3,33 & 1,08 \\
\hline F6_5. & $\begin{array}{l}\text { Tourism industry needs to contribute to } \\
\text { local budget for improving the quality of } \\
\text { life of the local community }\end{array}$ & 371 & 1 & 5 & 4,52 & 0,62 \\
\hline F6_6. & $\begin{array}{l}\text { Tourism industry contributes to the local } \\
\text { budget for improving the quality of life } \\
\text { in my area }\end{array}$ & 371 & 1 & 5 & 3,66 & 1,07 \\
\hline
\end{tabular}

Note: (1-I do not agree at all, 5- I fully agree)

Source: Local residents questionnaire, June 2016.

In this research local residents consider that tourism industry must contribute to the local budget for improving the quality of life of the local community (4,52), apropos even 57\% of subjects concur with this claim. Also $50 \%$ of subjects concur completely with the claim that Tourism industry should hire at least half of its employees from the local community giving it an average grade of 4,32. Subjects also consider that Tourism industry needs to use at least half of goods and services from the local community so that 
ToSEE - Tourism in Southern and Eastern Europe, Vol. 5, pp. 101-119, 2019

D. Birkić, A. Primužak, N. Erdeljac: SUSTAINABLE TOURISM DEVELOPMENT OF COASTAL

$42 \%$ of subjects completely agree with that claim and had it evaluated with the average grade 4,22. Local residents of researched destination also consider that tourism industry does not hire its employees from local areas giving the claim Tourism industry hires half of its employees from the local community by giving it the lowest average grade 3,33. The reason could be that researched coastal destinations, based on their demographic, do not have sufficient young workforce (evidence of decrease and ageing population), with young people leaving for better paid jobs in the sectors that operate the whole year round. Such low grades were given to the claim Tourism industry uses at least one half of the goods and services from the source of the local community, and an average grade of 3,41 is particularly worrying. Tourism needs to serve, among others, economic growth and development by encouraging domestic economy and economic growth. An average grade above, but still not sufficient enough, was given to the claim Tourism industry contributes to the local budget for the bettering of the quality of life in my area 3,66. We can safely conclude that subjects have clearly defined expectations from the tourism industry but are also aware that such expectations in researched coastal destinations are not achieved. Here it is important to note that the economic benefits from tourism need to be equally distributed in society. Local community bears the biggest burden of tourism development with the economy suffering the negative consequences of tourism development which means that the benefits that come out of tourism development need necessarily be aimed towards the satisfaction of the interests of the resident (local) population of the coastal tourism destination. As shown before, the active participation of the community is one of the most prioritized requests of sustainable tourism of the community and that is achieved by developing quality channels of communication that are opened between the local self-governing bodies and the local community. In developing long-term strategic plans of developing the coastal destination or strategic plans of tourism destination we find the term "participation of local residents" in their creating, but, however, a question is asked at which level and which force of impact do local residents really participate in creating strategic plans of tourism destination development in which they live.

In order to check the local residents' attitude regarding the need of local community engagement in tourism development subjects, local residents, were asked to rate the level of agreement, with the claims shown in table 8, with grades 1 to 5 (1- I do not agree at all; 5- I agree fully. 
ToSEE - Tourism in Southern and Eastern Europe, Vol. 5, pp. 101-119, 2019

D. Birkić, A. Primužak, N. Erdeljac: SUSTAINABLE TOURISM DEVELOPMENT OF COASTAL ...

Table 8: Subject estimates on the local community need for engagement in tourism development

\begin{tabular}{|l|l|c|c|c|c|c|}
\hline Code & $\begin{array}{l}\text { F-4. The attitudes towards the need } \\
\text { for engagement of the local } \\
\text { community in tourism development }\end{array}$ & N & Min & Max & Standard & St.Dev. \\
\hline F4_1. & $\begin{array}{l}\text { All members of interest groups should } \\
\text { be engaged in the decision-making } \\
\text { process regarding tourism in my area }\end{array}$ & 371 & 1 & 5 & 4,40 & 0,74 \\
\hline F4_2. & $\begin{array}{l}\text { Active participation of all interest } \\
\text { groups of the community in the } \\
\text { decision-making process regarding } \\
\text { tourism development is a prerequisite } \\
\text { for successful tourism development of } \\
\text { the community }\end{array}$ & 371 & 1 & 5 & 4,40 & 0,74 \\
\hline F4_3. & $\begin{array}{l}\text { Tourism industry must accept diverse } \\
\text { attitudes of all members of the } \\
\text { community's interest groups in } \\
\text { tourism development }\end{array}$ & 371 & 1 & 5 & 4,35 & 0,78 \\
\hline
\end{tabular}

Note: (1- I do not agree at all, 5- I agree fully)

Source: Local residents' questionnaire, June 2016

According to the results shown in Table 8, subjects mostly have positive attitudes regarding the need for inclusion of the local community in tourism development and that has been confirmed with a high average grade 4,38. The claim All members of interest groups should be engaged in the decision-making process regarding tourism in my area was given an average grade 4,40 and $52 \%$ of subjects fully agree with this claim. The claim Active participation of all interest groups of the community in the decision-making process regarding tourism development is a prerequisite for successful tourism development of the community was also given an average grade 4,40 while $53 \%$ of subjects fully agree with this claim. A lower grade was given to the claim Tourism industry must accept diverse attitudes by members of interest groups in the community regarding tourism development, an average grade 4,35 where $50 \%$ of participations said they fully agree with this claim.

According to the results of this research we can conclude that the attitude of local residents is that all members of interest groups of the local community must participate in the decision-making process of tourism development in their community and that such an approach is a prerequisite for successful tourism development of the community. Respectively, the tourism industry should, in its development, take into account the attitude of interest groups within the community, especially local residents. In order to avoid viewing strategic tourism plans as nothing more than the results of work of multinational consultants, which use various methods to enhance their reputation on the interest of attractive tourism regions and destinations. It is crucial to include members of all interest groups within the local community while creating them. The question that necessarily arises is how influential the extent of local community participation really is? Certain scientific circle claim that the local community participates in the development of strategic planning (e.g. Inskeep 1991; Dredgei Moore 1992; Dowling, 1993; Long i Nuckolls 1994) but the levels of participation may be really low. Participation here is limited to the possibility of commenting on the appropriateness of 
ToSEE - Tourism in Southern and Eastern Europe, Vol. 5, pp. 101-119, 2019

D. Birkić, A. Primužak, N. Erdeljac: SUSTAINABLE TOURISM DEVELOPMENT OF COASTAL

solutions chosen from by institutional planners, from where it is possible to say that consulting the local community definitely exists but local community participation is a much rarer occurrence. According to numerous authors, long-term strategic vision of the tourist destination should be developed by fulfilling the main prerequisite for sustainable tourism growth of the destination (Simpson, 2001). In order to estimate the strategic grasp of the development of tourism by the local community, table 9, subjects, local residents, were asked to grade the claims that deal with estimations regarding the strategic grasp of tourism development by using grades from 1 to 5 (1- I don't agree at all, 5- I agree fully).

Table 9: Descriptive statistic of subject estimation regarding the strategic grasp of tourism development by the local community

\begin{tabular}{|c|l|c|c|c|c|c|}
\hline Code & $\begin{array}{l}\text { F5. Strategic grasp of tourism } \\
\text { development by the local community }\end{array}$ & N & Min & Max & Standard & St.Dev. \\
\hline F5_1. & $\begin{array}{l}\text { Tourism industry needs to plan long- } \\
\text { term in collaboration with the local } \\
\text { community }\end{array}$ & 371 & 1 & 5 & 4,48 & 0,64 \\
\hline F5_2. & $\begin{array}{l}\text { Successful administration of tourism } \\
\text { requests strategic planning with the } \\
\text { wider local community }\end{array}$ & 371 & 1 & 5 & 4,48 & 0,62 \\
\hline F5_3. & $\begin{array}{l}\text { Local community should have a long- } \\
\text { term attitude with regard to tourism } \\
\text { development planning }\end{array}$ & 371 & 1 & 5 & 4,53 & 0,62 \\
\hline F5_4. & $\begin{array}{l}\text { Tourism industry, in collaboration with } \\
\text { the local community, should ensure the } \\
\text { quality of tourism experiences for future } \\
\text { visitors }\end{array}$ & 371 & 1 & 5 & 4,58 & 0,61 \\
\hline
\end{tabular}

Note: (1- I do not agree at all, 5- I fully agree)

Source: Local residents' questionnaire, June, 2016

Table 9 shows the estimates of subjects regarding the strategic planning of tourism development by the local community. Subjects graded the Strategic grasp of tourism development by the local community with an average grade 4,51. The claim Local community should have a long-term attitude with regard to tourism development of the area was given an average grade 4,53. Strategic planning of the development of tourism by the local community in the context of coastal tourism destination means that the attitude of numerous organizations and individuals, industry and local community representatives, needs to be drawn closer by mechanisms that allow subjects to participate in the creation of strategic destination plans. The claim Successful tourism administration requires strategic planning with a wider local community was graded with an average grade 4,48. According to that grade we can conclude that local residents clearly identify that without local cooperation and consensus of numerous members there can be no successfully developed concept of sustainable tourism development of researched coastal destinations. The establishment of the planning process between local members and the tourism industry will probably result in conflicts, and not compliance, and can be conducted in an environment in which the local administration has an inappropriate impact and strength. Regardless of that, subjects consider that Tourism industry needs to plan long.-term in collaboration with the local community, and that claim was graded with a high average grade 4,48 . However, one needs to have in mind 
ToSEE - Tourism in Southern and Eastern Europe, Vol. 5, pp. 101-119, 2019

D. Birkić, A. Primužak, N. Erdeljac: SUSTAINABLE TOURISM DEVELOPMENT OF COASTAL ...

that the tourism industry is fragmented and divided, as well as that within local community there are numerous interest groups with different development aims. The strategic planning as envisioned by the local community entails the inclusion of a whole range of participants that represent different attitudes and possible solutions and eases the fulfilment of the social consensus regarding guidelines for the future. It is necessary that the local community participates in and is encouraged to participate in the decisionmaking processes that will affect their lives.

\section{CONCLUSION}

The findings of this research show local residents' attitudes regarding the fulfilled level of tourism development and sustainable tourism development. Benefits which arise from the growth and tourism development need to be directed first to fulfil the interests of the local community and local residents and then satisfaction of interests of other members of the tourism industry. The main benefits that tourism brings to the local community are economic benefits such as income increases, additional livelihood, employment, additional capital investments in the community and the rise of public revenues. This research has shown that local residents have clearly stated aims and expectations from the tourism industry but are also aware that such expectations are not fulfilled or are fulfilled on a lesser scale that expected. Local residents' attitude needs to be taken into account during the decision-making process for future tourism development and local residents need to state their interest (employment, insuring a higher standard of living, the possibility of entrepreneurial activities, market for new products, the improvement of infrastructure and so on). Organs of local-self-government are those that need to follow and identify the needs and expectations of local residents, local community and direct their activities to fulfilling them. Also, it is necessary that the local selfgovernment avoids formal legal inclusion of the local community in the process of strategic planning, which should stay on the level of commenting without real intention of respecting the stated attitudes regarding the question of sustainable tourism development. The initiative for the development of tourism based on the principles of sustainable tourism should come from the local community, local residents, who need to grasp that, in tourism, economic benefits are brought on by ecological responsibilities, apropos, not depleting the natural environment as the primary tourism resource and preserving natural and build attractions. The key task of those responsible for the growth development, the development agencies, is to improve the channels of communication and coordination between the holder of development, the planners and the local community. The qualification of the local community for participation in the development plans through various education, with the aim of taking over responsibilities regarding sustainable tourism development of the destination. 
ToSEE - Tourism in Southern and Eastern Europe, Vol. 5, pp. 101-119, 2019

D. Birkić, A. Primužak, N. Erdeljac: SUSTAINABLE TOURISM DEVELOPMENT OF COASTAL ...

\section{REFERENCES}

Altinay, L. and Bowen, D. (2006), "Politicals and tourism interface: the case of Cyprus", Annals of Tourism Research, Vol. 33, No. 4, pp. 939-956. doi: 10.1016/j.annals.2006.03.020

Birkić, D., Čubelić Pilija, I. and Kljajić Šebrek, J.(2014), "The role of local goverment in planning of sustainable tourism of coastal destination", 22nd Biennial International Congress, Tourism \& Hospitality Industry 2014, Trends in Tourism and Hospitality Managament, Scientific paper ISSN 1848-4581, Opatija, 08.-09. May 2014.g.

Bramwell, B. (2011), "Governance, the state and sustainable tourism: a political economy approach", Journal of Sustainable Tourism, Vol. 19, No.4-5, pp. 459-477.

Burns, P. (2008), “Tourism, political discourse and postcolonialism", Tourism and Hospitality: Planing \& Development, Vol. 6, No. 1, pp. 61-73.

Choi, H.C. and Murray, I. (2010), "Resident attitudes toward sustainable community tourism", Journal of Sustainable Tourism, Vol. 18, No. 4,pp. 575-594. https://doi.org/10.1080/09669580903524852

Choi, H.C., and Sirakaya, E. (2005), "Measuring Residents'Attitude toward Sustainable Tourism: Development of Sustainable Tourism Attitude Scale", Journal of Tourism Research, Vol. 43, No. 4, pp. 380-394. doi/10.1177/0047287505274651

Choi, H.C. and Sirakaya, E. (2006), "Sustainability indicators for managing community tourism", Tourism Management, Vol. 27, No. 6, pp. 1274-1289.doi:10.1016/j.tourman 2005.05.18

Churchill, Gilbert, A.Jr. (1979), "A Paradigm for Developing Beter Measures of Marketing Constructs", Journal of Marketing Research, Vol. 16, No. 1, pp.64-73.

Cole, S. (2006), "Information and empowerment:The keys to achieving sustainable tourism". Journal of Sustainable Tourism, Vol. 14, No. 6, pp. 629-644. doi:10.2167/jost607.0

De Vellis, Robert F.(1991), Scale Development:Theory and Applications, Newbury Park, CA:Sage.

Dowling, R.K. (1993), "An environmentally based planning model for regional tourism development", Journal of Sustainable Tourism, Vol. 1, No. 1, pp. 17-37. doi:10.1080/09669589309450698

Dredge, D. and Moore, S. (1992), "A methodology for the integration of tourism in town planning", Journal of Tourism Studies, Vol. 3, No. 1, pp. 8-21.

Inskeep, E. (1991), Tourism Planning - An Integrated and Sustainable Development Approach, John Wiley \& sons, inc., New York.

Jamal, T. and Getz, D. (1995), "Collaboration theory and community tourism planninig", Annals of Tourism Research, Vol. 22, No. 1,pp. 186-204.

Jamal,T. and Camargo, B.A. (2013), "Sustainable tourism, justice and an ethic of care. Toward the Just Destination", Journal of Sustainable Tourism, Vol. 22, No. 1, pp. 11-30. doi:10.1080/09669582.2013.786084

Joppe, M. (1996), "Sustainable community tourism development revisited", Tourism Managament, Vol. 17, No. 7, pp. 475-479. doi:10.1016/s0261-5177(96)00065-9

Jurowski, C. and Gursoy, D. (2004), "Distance effects on residents' attitudes toward tourism", Annals of Tourism Research, Vol. 31, No. 2, pp. 269-312. doi:10.1016/j.annals.2003.12.005

Lankford, S.V. and Howard, D.R. (1994), "Developing a tourism impact attitude scale", Annals of Tourism Research, Vol. 21, No. 1, pp. 121-139. https://doi.org/10.1016/0160-7383(94)90008-6.

Long, P. and Nuckolls, J. (1994), "Organising resources for rural tourism development: The importance of leadership, planning and technical assistance", Tourism Recreation Research, Vol. 19, No. 2, pp. 19-34. doi:10.1080/025821.1994.11014705

Low, H.A. and Smart, A. (1998), "Social aspect of tourism and development", In Tisdell, C.A., Roy, K.C. (Eds.), Tourism and Development:Economic, social, political and economic issues, Commack, NY: Nova Science, pp. 69-91.

Murphy, P.E. (1985), Tourism: A community approach, Methuen, New York.

Murphy, P.E. (1981), “Community attitudes to tourism: A comparative analysis”, International Journal of Tourism Management, Vol. 2, No. 3, pp. 189-195. https://doi.org/10.1016/0143-2516(81)90005-0

Petrić, L. (2011.), Upravljanje turističkom destinacijom, Ekonomski fakultet, Split.

Saufi, A., O'Brien, D. and Wilkins, H. (2014), "Inhibitors to host community partipation in sustainable tourism development in developing countries", Journal of Sustainable Tourism, Vol. 22, No. 5, pp. 801820. https://doi.org/10.1080/09669582.2013.861468

Scheyvens, R. (2002), Tourism for development empowering communities, Pearson Education, Essex.

Shamsul-Haque, M. (2007), "Theory and practice of public administrtion in Southeast Asia: traditions, directions and impacts", International Journal of Public Administration, No. 30, pp. 1297-1326. doi: 10.1080/01900690701229434

Teye,V., Sirakaya, E., and Sönmez, S. (2002), "Residents' attitudes toward tourism development”, Annals of Tourism Research, Vol. 29, No. 3, pp. 668-688. doi:10.1016/s0160-7383(01)00074-3 
ToSEE - Tourism in Southern and Eastern Europe, Vol. 5, pp. 101-119, 2019

D. Birkić, A. Primužak, N. Erdeljac: SUSTAINABLE TOURISM DEVELOPMENT OF COASTAL ...

Thimothy, D.J. (1999), "Participatory planning :A view of tourism in Indonesia", Annals of Tourism Research, Vol. 26, No. 2, pp. 371-391.

Tosun, C. (2006), "Expected nature of community participation in tourism development", Tourism Managament, Vo. 27, No. 3, pp. 559-576. doi:10.1016/j.tourman.2004.12.004

Trousdale, W.J. (1999), "Governance in context, Boracay Island, Philippines", Annals of Tourism Research, 2684, pp. 840-860.

Weawer, D. and Lawton, L. (2006), Tourism management, Wiley, Milton.

Draženka Birkić, PhD, Senior Lecturer

Karlovac University of Applied Sciences

Business Department

Trg J.J. Strossmayera 9, 47000 Karlovac, Croatia

Phone: 047/843-519

E-mail: dbirkic@vuka.hr

Andreja Primužak, BSc, Lecturer

Karlovac University of Applied Sciences

Business department

Trg J.J. Strossmayera 9, 47000 Karlovac, Croatia

Phone: 047/843-541

E-mail: andreja.primuzak@vuka.hr

mag.educ.hist.et.philol.angl. Nela Erdeljac, Assistant

Karlovac University of Applied Sciences

Business Department

Trg J.J. Strossmayera 9, 47000 Karlovac, Croatia

Phone: 047/843-590

E-mail: nerdeljac@vuka.hr 